\title{
Development and Oviposition of Tetranychus pueraricola Ehara and Gotoh (Acari: Tetranychidae) on Various Plants
}

\author{
Tetsuo GoтOH*, Akiyuki SuWA ${ }^{\dagger}$ and Yasuki KITASHIMA \\ Laboratory of Applied Entomology and Zoology, Faculty of Agriculture, Ibaraki University, Ami, \\ Ibaraki 300-0393, Japan
}

(Received 7 June 2004; Accepted 8 September 2004)

\begin{abstract}
The spider mite Tetranychus pueraricola is widely distributed throughout Japan and it is common on kudzu vine but not on crops. Because this species has the second highest $r_{\mathrm{m}}$-value among tetranychid mites studied so far, there is a real possibility that $T$. pueraricola will get out of hand after invasion of agricultural crops. To better evaluate its potential severity as a pest, we examined the host range of five populations collected from kudzu vine. On leaf discs juvenile survival to adulthood was assessed, as well as egg production of young females over a period of five days. Out of 23 potential host plant species in 12 families tested, $70 \%$ or more larvae attained maturity and 15 or more eggs were subsequently laid by mites of all five populations on nine plantspecies (soybean, lima bean, kidney bean, kudzu vine, cowpea, spinach, apricot, rose and mulberry), whereas no or few larvae attained maturity on another four species (cucumber, tomato, chrysanthemum and Satsuma mandarin). On watermelon, strawberry and eggplant four of the five populations performed well. These results indicate that $T$. pueraricola has a broad potential host plant range, just like other polyphagous spider mite species, which are all serious pests. Its broad host range plus the second highest $r_{\mathrm{m}}$-value among Tetranychus species, suggest that this species has the potential to become a serious pest on agricultural crops.
\end{abstract}

Key words: Tetranychus pueraricola, host range, polyphagy, bean, trichome

\section{INTRODUCTION}

The spider mite Tetranychus pueraricola Ehara and Gotoh was first found infesting kudzu vine, Pueraria lobata (Willd.), in Ibaraki Prefecture, central Japan, and was described as a new species by Ehara and Gotoh (1996). This species is closely related to the two-spotted spider mite T. urticae Koch (red form). In fact, hybrid females can unidirectionally reproduce in crosses between females of $T$. pueraricola and males of T. urticae, but these hybrids are either sterile or lay only inviable eggs (Gotoh and Tokioka, 1996). T. pueraricola is discriminated from T. urticae by the size of the knob on the aedeagus, which is about $2.1 \mu \mathrm{m}$ for the former and about $2.5 \mu \mathrm{m}$ for the latter (Ehara and Gotoh, 1996), i.e., one has to be an expert to see the difference between the two species. Although T. pueraricola is widely distributed throughout Japan, it is known only from kudzu vines ( $P$. lobata on the main islands and P. montana (Lour.) on Okinawa Islands) (Gotoh and Tokioka, 1996; Gotoh et al.,

\footnotetext{
*Corresponding author: e-mail: gotoh@mx.ibaraki.ac.jp; phone and fax: +81-29-888-8560

†Present address: Nihon Nohyaku Co., Ltd., Oyamada 345, Kawachi-Nagano, Osaka 586-0094, Japan

:Present address: Fuji Environmental Service Co., Ltd., 5-5-7 Hirono, Shizuoka 421-0121, Japan
} 
1996, 2003). Nevertheless, it cannot be ruled out that this species incidentally outbreaks after invasion of agricultural crops, because our previous study showed that it has high reproductive capacity - the intrinsic rate of natural increase $\left(r_{\mathrm{m}}\right)$ equals 0.299 day $^{-1}$ at $25^{\circ} \mathrm{C}$ (Gotoh et al., 2004), which is the second highest value among tetranychid mites studied so far (Sabelis, 1985, 1991; Takafuji et al., 1996). Therefore, to better evaluate its potential severity as a pest we need to know, in addition to its reproductive performance, the basic ecological traits of T. pueraricola such as host range and its susceptibility to acaricides.

In this study, the host range of five T. pueraricola populations collected from kudzu vine at different localities was examined, with special attention to agricultural crops on which the closely related $T$. urticae and $T$. kanzawai Kishida are known to occasionally reach pest status.

\section{MATERIALS AND METHODS}

Table 1 summarizes the five populations used in this study. Laboratory stock cultures of T. pueraricola have been maintained on leaf discs (ca. $25 \mathrm{~cm}^{2}$ ) of kidney bean (Phaseolus vulgaris L.) placed on a water-saturated polyurethane mat in a plastic dish $(9 \mathrm{~cm}$ diam.). All experiments were carried out at $25 \pm 1^{\circ} \mathrm{C}, 60-70 \%$ R.H. and a $16 \mathrm{~L}: 8 \mathrm{D}$ photoperiod. Experiments were performed in 1997, thus the populations used were maintained in the laboratory for two-four years.

Juvenile survival, development and reproductive performance of five populations were examined on 23 potential host plant species in 12 families. About 10 newly hatched larvae from each population were randomly selected from the stock cultures and placed onto each of 6 to 12 leaf discs (ca. 16-25 $\mathrm{cm}^{2}$ ) of the test plant leaves; in total 58-120 larvae were examined for each plant. The survivors were counted daily on all leaf discs until the mites reached adulthood, and then the survival rate from larva to adult ((number of adults emerged/number of larvae tested $\times 100$ ) was calculated. Females in the teleiochrysalis stage, which developed on the test plants, were individually transferred onto new leaf discs and kept with an adult male for mating. The males were removed 2 days after emergence of the adult females. After oviposition started, each female was allowed to lay eggs for 5 days after which the number of eggs laid was recorded. Various criteria have been in use to determine host plants in spider mites (Gotoh and Noguchi, 1990; Osakabe, 1993; Gomi and Gotoh, 1996; Gotoh and Higo, 1997), which accounts for the difficulty in comparing host ranges among conspecific populations or among populations of closely related species. In this study, we determined both survival rates in immature stages and the total number of

Table 1. Collection data of five Tetranychus pueraricola populations used in this study

\begin{tabular}{lccl}
\hline \multicolumn{1}{c}{ Locality (Population) } & Geographic coordinates & Date & \multicolumn{1}{c}{ Host plant } \\
\hline Matsuo, Iwate (MT) & $39^{\circ} 58^{\prime} \mathrm{N}-140^{\circ} 56^{\prime} \mathrm{E}$ & 26 July, 1994 & Pueraria lobata \\
Tazawako, Akita (TZ) & $39^{\circ} 45^{\prime} \mathrm{N}-140^{\circ} 41^{\prime} \mathrm{E}$ & 26 July, 1994 & P. lobata \\
Hitachi-Ohta, Ibaraki (HO) & $36^{\circ} 32^{\prime} \mathrm{N}-140^{\circ} 34^{\prime} \mathrm{E}$ & 23 Oct., 1993 & P. lobata \\
Kikuyo, Kumamoto (KK) & $32^{\circ} 51^{\prime} \mathrm{N}-130^{\circ} 47^{\prime} \mathrm{E}$ & 10 June, 1994 & P. lobata \\
Nago, Okinawa (NG) & $26^{\circ} 35^{\prime} \mathrm{N}-127^{\circ} 59^{\prime} \mathrm{E}$ & 2 Aug., 1995 & Pueraria montana \\
\hline
\end{tabular}


eggs laid during the first five days of the oviposition period for females which had matured on the potential host plant species.

\section{RESULTS AND DISCUSSION}

Table 2 shows the developmental success and the total number of eggs laid per female on 23 potential host plants for the five populations of T. pueraricola. Whenever larvae attained maturity they did so within 9 days after inoculation, regardless of the test plant species. No or few larvae attained maturity on four plants (cucumber, tomato, chrysanthemum and Satsuma mandarin), because most individuals died during the larval and protonymphal stages. On another nine potential host plants mites of all five populations performed well: on soybean, lima bean, kidney bean, kudzu vine, cowpea, spinach, apricot, rose and mulberry $70 \%$ or more larvae attained maturity and females laid 15 or more eggs in the following five days. Watermelon and strawberry were suitable hosts for all but the NG population, eggplant for all but the HO population.

On apple and Japanese plum, larvae developed successfully but fecundity was around 10 eggs in five days. About half to one-third of the individuals attained maturity on Japanese pear and grapevine, but no or few eggs were deposited by females. Survival rates among populations were variable on cabbage, maize and American cotton, while fecundity was either low (on cabbage and maize) or high (on cotton). Many immature individuals were entrapped by trichomes on the cotton leaf surface, resulting in a low maturity rate. In contrast, fecundity on cotton was high for all five populations, suggesting that the trichomes do not severely influence oviposition of the adults. A similar tendency is known for the spittlebug, Philaenus spumarius (L.), infesting cotton. Trichomes on leaves impeded feeding of early-instar larvae but did not affect the larger instars of $P$. spumarius (Bernays and Chapman, 1994).

The variability on watermelon and eggplant (survival rates) and on strawberry (fecundity) seems very interesting for further studies into the presence of trade-offs and/or host race formation-four of the five populations perform really well, but the fifth remarkably bad.

T. okinawanus, which is less abundant on agricultural crops in the sub-tropical region, also did not accept cucumber, tomato, chrysanthemum or Satsuma mandarin (Takafuji et al., 1996). Often spider mites have difficulty to infest cucumber and tomato (Gould, 1979; Fry, 1989; Gotoh et al., 1993), because toxic substances of bitter cucumber varieties result in high juvenile mortality (Gould, 1979), and glandular hairs on tomato lead to high mite mortality due to entrapment and intoxication (Chatzivasileiadis and Sabelis, 1997, 1998).

That individuals were found to perform and oviposit on nineteen out of 23 test plant species indicates that $T$. pueraricola has a broad potential host range, just like polyphagous spider mite species such as T. urticae (Bolland et al., 1998), T. kanzawai (Gomi and Gotoh, 1996) and T. okinawanus Ehara (Takafuji et al., 1996). Although it is very difficult to explain why T. pueraricola is not yet known as a pest of agricultural crops, there are several theoretical possibilities. T. pueraricola may frequently invade agricultural crops, but disappear again rapidly because (1) the mites are highly susceptible to agricultural chemicals, (2) they loose resource competition with other mite species, or (3) they may be vulnerable to the 
Table 2. Developmental success of five populations of $T$. pueraricola from larva to adult (\% Maturity) and number of eggs laid during the first five days of oviposition on various plants. See Table 1 for explanation of the population abbreviations.

\begin{tabular}{|c|c|c|c|c|c|c|c|c|c|c|}
\hline \multirow{2}{*}{ Test plant (variety) [English name] } & \multicolumn{5}{|c|}{$\%$ Maturity $^{\mathrm{a}}$} & \multicolumn{5}{|c|}{ Total no. of eggs per female $(N)^{\mathrm{b}}$} \\
\hline & MT & $\mathrm{TZ}$ & $\mathrm{HO}$ & KK & NG & MT & $\mathrm{TZ}$ & $\mathrm{HO}$ & KK & NG \\
\hline \multicolumn{11}{|l|}{ Leguminosae } \\
\hline Glycine max (Iwahime) [soybean] & 82.8 & 91.7 & 93.3 & 95.0 & 90.0 & $\begin{array}{l}42.8 \\
(26)\end{array}$ & $\begin{array}{l}45.4 \\
(23)\end{array}$ & $\begin{array}{l}47.0 \\
(29)\end{array}$ & $\begin{array}{l}44.1 \\
(23)\end{array}$ & $\begin{array}{l}38.4 \\
(26)\end{array}$ \\
\hline Phaseolus lunatus [lima bean] & 90.0 & 88.3 & 86.7 & 98.3 & 96.7 & $\begin{array}{l}38.9 \\
(20)\end{array}$ & $\begin{array}{l}35.3 \\
(22)\end{array}$ & $\begin{array}{l}36.6 \\
(24)\end{array}$ & $\begin{array}{l}34.8 \\
(22)\end{array}$ & $\begin{array}{l}23.2 \\
(21)\end{array}$ \\
\hline Phaseolus vulgaris (Nagauzura-mame) [kidney bean] & 94.8 & 88.3 & 98.3 & 93.1 & 98.3 & $\begin{array}{l}42.1 \\
(28)\end{array}$ & $\begin{array}{l}47.3 \\
(31)\end{array}$ & $\begin{array}{l}49.9 \\
(29)\end{array}$ & $\begin{array}{l}40.4 \\
(28)\end{array}$ & $\begin{array}{l}37.5 \\
(30)\end{array}$ \\
\hline Pueraria lobata [kudzu vine] & 93.3 & 96.7 & 98.3 & 95.0 & 93.3 & $\begin{array}{l}36.3 \\
(32)\end{array}$ & $\begin{array}{l}41.6 \\
(32)\end{array}$ & $\begin{array}{l}37.9 \\
(32)\end{array}$ & $\begin{array}{l}35.6 \\
(31)\end{array}$ & $\begin{array}{l}22.0 \\
(35)\end{array}$ \\
\hline Vigna sinensis (Akatane-sanjyaku-oonaga) [cowpea] & 88.3 & 93.3 & 91.7 & 96.7 & 93.3 & $\begin{array}{l}29.6 \\
(31)\end{array}$ & $\begin{array}{l}31.1 \\
(30)\end{array}$ & $\begin{array}{l}31.3 \\
(30)\end{array}$ & $\begin{array}{l}32.4 \\
(27)\end{array}$ & $\begin{array}{l}21.2 \\
(27)\end{array}$ \\
\hline \multicolumn{11}{|l|}{ Cucurbitaceae } \\
\hline Citrullus lanatus (Kogane-daio) [watermelon] & 73.3 & 76.7 & 74.3 & 70.0 & 2.5 & $\begin{array}{l}26.3 \\
(17)\end{array}$ & $\begin{array}{l}22.8 \\
(19)\end{array}$ & $\begin{array}{l}27.7 \\
(18)\end{array}$ & $\begin{array}{l}22.8 \\
(19)\end{array}$ & $-^{c}$ \\
\hline Cucumis sativus (Sharp-one) [cucumber] & 0 & 0 & 0 & 0 & 0 & - & - & - & - & - \\
\hline \multicolumn{11}{|l|}{ Solanaceae } \\
\hline Lycopersicon esculentum (Momotaro) [tomato] & 0 & 0 & 0 & 0 & 3.3 & - & - & - & - & - \\
\hline Solanum melongena (Senryo-nigo) [eggplant] & 88.3 & 96.7 & 50 & 96.7 & 95.0 & $\begin{array}{l}29.3 \\
(30)\end{array}$ & $\begin{array}{l}27.0 \\
(30)\end{array}$ & $\begin{array}{l}18.4 \\
(18)\end{array}$ & $\begin{array}{l}25.6 \\
(28)\end{array}$ & $\begin{array}{l}21.0 \\
(31)\end{array}$ \\
\hline \multicolumn{11}{|l|}{ Chenopodiaceae } \\
\hline Spinacia oleracea (Musashi) [spinach] & 80.0 & 90.0 & 85.0 & 90.8 & 85.0 & $\begin{array}{l}34.3 \\
(29)\end{array}$ & $\begin{array}{l}35.4 \\
(30)\end{array}$ & $\begin{array}{l}32.8 \\
(30)\end{array}$ & $\begin{array}{l}31.2 \\
(23)\end{array}$ & $\begin{array}{l}18.5 \\
(28)\end{array}$ \\
\hline \multicolumn{11}{|l|}{ Cruciferae } \\
\hline $\begin{array}{l}\text { Brassica oleracea (Kinkei-201) [cabbage] } \\
\text { Gramineae }\end{array}$ & 76.7 & 78.3 & 63.3 & 86.7 & 33.3 & $\begin{array}{l}1.6 \\
(11)\end{array}$ & $\begin{array}{r}3.2 \\
(16)\end{array}$ & $\begin{array}{r}3.0 \\
(11)\end{array}$ & $\begin{array}{l}3.4 \\
(7)\end{array}$ & $\begin{array}{l}1.0 \\
(3)\end{array}$ \\
\hline Zea mays (Honey bantam) [maize] & 22.5 & 56.7 & 75.8 & 41.7 & 48.3 & $\begin{array}{r}5.6 \\
(10)\end{array}$ & $\begin{array}{r}7.9 \\
(14)\end{array}$ & $\begin{array}{r}6.7 \\
(13)\end{array}$ & $\begin{array}{r}6.2 \\
(12)\end{array}$ & $\begin{array}{r}5.2 \\
(11)\end{array}$ \\
\hline \multicolumn{11}{|l|}{ Malvaceae } \\
\hline Gossypium herbaceum (American cotton) [cotton] & 35.0 & 67.5 & 69.2 & 65.8 & 62.5 & $\begin{array}{l}17.3 \\
(19)\end{array}$ & $\begin{array}{l}18.5 \\
(28)\end{array}$ & $\begin{array}{l}24.2 \\
(27)\end{array}$ & $\begin{array}{l}23.6 \\
(16)\end{array}$ & $\begin{array}{l}18.5 \\
(27)\end{array}$ \\
\hline \multicolumn{11}{|l|}{ Compositae } \\
\hline Chrysanthemum sp. (58 go) [chrysanthemum] & 0 & 0 & 0 & 0 & 0 & - & - & - & - & - \\
\hline \multicolumn{11}{|l|}{ Rosaceae } \\
\hline Fragaria $\mathrm{x}$ ananassa (Nyoho) [strawberry] & 90.0 & 98.3 & 96.7 & 91.7 & 100 & $\begin{array}{l}23.6 \\
(28)\end{array}$ & $\begin{array}{l}17.6 \\
(24)\end{array}$ & $\begin{array}{l}27.4 \\
(27)\end{array}$ & $\begin{array}{l}26.6 \\
(20)\end{array}$ & $\begin{array}{r}6.7 \\
(25)\end{array}$ \\
\hline Malus pumila var. domestica (Fuji) [apple] & 90.0 & 86.7 & 88.3 & 90.0 & 91.7 & $\begin{array}{l}13.7 \\
(26)\end{array}$ & $\begin{array}{l}10.2 \\
(26)\end{array}$ & $\begin{array}{l}13.1 \\
(27)\end{array}$ & $\begin{array}{l}11.1 \\
(25)\end{array}$ & $\begin{array}{r}9.0 \\
(28)\end{array}$ \\
\hline Prunus armeniaca (Heiwa) [apricot] & 85.0 & 80.0 & 93.3 & 81.3 & 91.7 & $\begin{array}{l}27.1 \\
(27)\end{array}$ & $\begin{array}{l}28.6 \\
(27)\end{array}$ & $\begin{array}{l}32.6 \\
(31)\end{array}$ & $\begin{array}{l}26.2 \\
(32)\end{array}$ & $\begin{array}{l}20.7 \\
(32)\end{array}$ \\
\hline Prunus salicina (Beni-sumomo) [Japanese plum] & 83.3 & 86.7 & 90.0 & 86.7 & 90.0 & $\begin{array}{l}13.1 \\
(32)\end{array}$ & $\begin{array}{l}13.9 \\
(30)\end{array}$ & $\begin{array}{l}12.1 \\
(29)\end{array}$ & $\begin{array}{l}12.1 \\
(28)\end{array}$ & $\begin{array}{r}9.5 \\
(29)\end{array}$ \\
\hline Pyrus serotina var. culta (Hosui) [Japanese pear] & 33.3 & 40.0 & 58.3 & 31.7 & 35.0 & $\begin{array}{l}1.0 \\
(2)\end{array}$ & - & $\begin{array}{r}3.2 \\
(12)\end{array}$ & - & - \\
\hline Rosa sp. (Blue-river) [rose] & 85.0 & 88.3 & 93.3 & 85.0 & 91.7 & $\begin{array}{l}28.8 \\
(21)\end{array}$ & $\begin{array}{l}33.8 \\
(18)\end{array}$ & $\begin{array}{l}27.2 \\
(22)\end{array}$ & $\begin{array}{l}25.0 \\
(19)\end{array}$ & $\begin{array}{l}17.4 \\
(19)\end{array}$ \\
\hline \multicolumn{11}{|l|}{ Vitaceae } \\
\hline Vitis labrusca (Delaware) [grapevine] & 44.2 & 43.3 & 45.8 & 40.3 & 45.8 & $\begin{array}{r}6.2 \\
(17)\end{array}$ & $\begin{array}{r}4.5 \\
(11)\end{array}$ & $\begin{array}{r}6.6 \\
(18)\end{array}$ & $\begin{array}{r}4.8 \\
(12)\end{array}$ & $\begin{array}{r}3.9 \\
(13)\end{array}$ \\
\hline \multicolumn{11}{|l|}{ Rutaceae } \\
\hline Citrus unshiu (Unshiu) [Satsuma mandarin] & 0 & 0 & 0 & 0 & 0 & - & - & - & - & - \\
\hline \multicolumn{11}{|l|}{ Moraceae } \\
\hline Morus bombycis (Ichinose) [mulberry] & 83.3 & 95.0 & 96.7 & 93.3 & 90.0 & $\begin{array}{l}16.3 \\
(30)\end{array}$ & $\begin{array}{l}18.9 \\
(32)\end{array}$ & $\begin{array}{l}20.0 \\
(30)\end{array}$ & $\begin{array}{l}17.4 \\
(26)\end{array}$ & $\begin{array}{l}15.4 \\
(31)\end{array}$ \\
\hline
\end{tabular}


artificial disturbance of the agricultural habitat and quickly migrate from there to anotheras a result they would easily go unnoticed. Finally, it could also be that T. pueraricola does incidentally reach pest status, but that they are simply misidentified as T. urticae, due to the minute morphological differences between the two species. Nevertheless, as was pointed out for T. okinawanus by Takafuji et al. (1996), its polyphagous nature (Table 2) and high reproductive capacity (Gotoh et al., 2004) potentially enables it to become a serious pest on agricultural crops. Consequently, we should prepare for the invasion by $T$. pueraricola of agricultural crops from a nearby kudzu vine where the mites are abundant, and expect that they get out of hand, especially on leguminous plants. This means that we need to gain insight into its susceptibility to insecticides and acaricides, to detect chemicals for control when it incidentally increases on agricultural crops. In addition, the ecological performance of $T$. pueraricola needs to be clarified, such as its seasonal prevalence, its native host plants and whether it can establish on leguminous crops when it is artificially inoculated.

\section{ACKNOWLEDGEMENTS}

We are indebted to J. Bruin, University of Amsterdam, for his invaluable comments.

\section{REFERENCES}

Bernays, E. A. and R. F. Chapman (1994) Host-Plant Selection by Phytophagous Insects. 312 p., Chapman \& Hall, New York.

Bolland, H. R., J. Gutierrez and C. H. W. Flechtmann (1998) World Catalogue of the Spider Mite Family (Acari: Tetranychidae). 392 p., Brill, Leiden.

Chatzivasileiadis, E. A. and M. W. Sabelis (1997) Toxicity of methyl ketones from tomato trichomes to Tetranychus urticae Koch. Experimental and Applied Acarology, 21: 473-484.

Chatzivasileiadis, E. A. and M. W. Sabelis (1998) Variability in susceptibility among cucumber and tomato strains of Tetranychus urticae Koch to 2-tridecanone from tomato trichomes: effects of host plant shift. Experimental and Applied Acarology, 22: 455-466.

Ehara, S. and T. Gotoh (1996) Two new species of spider mites occurring in Japan (Acari: Tetranychidae). Journal of the Acarological Society of Japan, 5: 17-25.

Fry, J. D. (1989) Evolutionary adaptation to host plants in a laboratory population of the phytophagous mite Tetranychus urticae Koch. Oecologia, 81: 559-565.

Gomi, K. and T. Gotoh (1996) Host plant preference and genetic compatibility of the Kanzawa spider mite, Tetranychus kanzawai Kishida (Acari: Tetranychidae). Applied Entomology and Zoology, 31: 417-425.

Gotoh, T. and Y. Higo (1997) Differences in host range and reproductive compatibility among populations of Panonychus mori Yokoyama (Acari: Tetranychidae). International Journal of Acarology, 23: 119-125.

Gotoh, T. and O. Noguchi (1990) Developmental success and reproductive incompatibility among populations of the European red mite, Panonychus ulmi (Acari: Tetranychidae). Experimental and Applied Acarology, 10: 157165.

Gotoh, T. and T. Tokioka (1996) Genetic compatibility among diapausing red, non-diapausing red and diapausing green forms of the two-spotted spider mite, Tetranychus urticae Koch (Acari: Tetranychidae). Japanese Journal of Entomology, 64: 215-225.

Gotoh, T., J. Bruin, M. W. Sabelis and S. B. J. Menken (1993) Host race formation in Tetranychus urticae: genetic differentiation, host plant preference, and mate choice in a tomato and a cucumber strain. Entomologia Experimentalis et Applicata, 68: 171-178.

Gotoh, T., A. Takafuji and K. Gomi (1996) Tetranychid mites of Okinawa Island (Acari: Tetranychidae). Journal of the Acarological Society of Japan, 5: 89-94. 
Gotoh, T., H. Noda and X.-Y. Hong (2003) Wolbachia distribution and cytoplasmic incompatibility based on a survey of forty-two spider mite species (Acari: Tetranychidae) in Japan. Heredity, 91: 208-216.

Gotoh, T., A. Suwa, Y. Kitashima and H. A. Rezk (2004) Developmental and reproductive performance of Tetranychus pueraricola Ehara and Gotoh (Acari: Tetranychidae) at four constant temperatures. Applied Entomology and Zoology, 39: 675-682.

Gould, F. (1979) Rapid host range evolution in a population of the phytophagous mite Tetranychus urticae. Evolution, 33: 791-802.

Osakabe, Mh. (1993) Divergence of the northern and southwestern populations of Panonychus mori Yokoyama (Acari: Tetranychidae) in Japan in host range and reproductive compatibility. Applied Entomolgy and Zoology, 28: 189-197.

Sabelis, M. W. (1985) Reproductive strategies. In: Spider Mites: Their Biology, Natural Enemies and Control, 1A (eds., Helle, W. and M. W. Sabelis), pp. 265-278., Elsevier, Amsterdam.

Sabelis, M. W. (1991) Life-history evolution of spider mites. In: The Acari. Reproduction, Development and LifeHistory Strategies (eds., Schuster, R. and P. W. Murphy). pp. 23-49., Chapman \& Hall, London.

Takafuji, A., T. Yokotsuka, K. Goka and H. Kishimoto (1996) Ecological performance of the spider mite, Tetranychus okinawanus Ehara (Acari, Tetranychidae), a species newly described from Okinawa Islands (1). Journal of the Acarological Society of Japan, 5: 75-81.

\section{摘要}

ナミハダニモドキの 5 個体群における寄主範囲

後藤 哲雄・諏訪 明之・北嶋 康樹（茨城大学農学部）

ナミハダニモドキは日本各地のクズに寄生し，葉上に顕著な褐色の食害痕を出すが，その 生態は不明である. 本研究では, 寄主植物の面から害虫化する可能性を推測するため, 各地 から採集したナミハダニモドキの 5 個体群について, それらの寄主範囲を検討した。 供試し た 12 科 23 種の植物のらち，5 個体群すべてに共通する寄主植物は 4 科 9 種類であった（ダ イズ,リママメ，インゲンマメ，クズ，ササゲ，ホウレンソウ，スモモ，バラ，クワ)。スイ カとイチゴでは, 名護（沖縄県）の個体群を除く 4 個体群，ナスでは常陸太田（茨城県）を 除く 4 個体群がそれぞれ良好な発育と産卵数を結果し, 寄主植物であった。 このように, 本 種はナミハダニやカンザワハダニなどの広食性で害虫種となっているハダニと同等の広い寄 主範囲をもつことが分かった。 ナミハダニモドキは広食性であり， $25^{\circ} \mathrm{C} に$ 打ける内的自然増 加率 $\left(r_{\mathrm{m}}\right)$ は同属のナンゴクナミハダニに次ぐ高いものであったことから, 本種が農生態系 に侵入した場合，重要な害虫になる可能性が考えられた. 